\title{
Mark-Up Pricing in Bulgarian Manufacturing
}

By: Rumen Dobrinsky, Boyko Nikolov, and Nikolay Markov

William Davidson Working Paper Number 389

June 2001 


\title{
MARK-UP PRICING IN BULGARIAN MANUFACTURING
}

\begin{abstract}
The pricing policy of Bulgarian manufacturing firms is analysed in the paper in the context of the theory of the price-setting behaviour of firms endowed with market power, and more specifically, using the notion of mark-up pricing. Using some recent derivations in the literature, we estimate mark-up ratios for Bulgarian manufacturing sectors at the NACE 2digit and NACE 3-digit levels. The estimated mark-ups are then tested against a set of variables measuring the degree of competitive pressure on a sectoral level.
\end{abstract}

JEL Classification numbers: C23, D21, D24

Keywords: mark-up pricing; competitive pressure; enterprise restructuring and adjustment, Bulgaria

${ }^{*}$ UN Economic Commission for Europe; Palais des Nations, CH-1211 Geneva tel. (+41 22) 917 2487; fax: (+41 22) 917 0309; e-mail: rumen.dobrinsky@unece.org

**) Centre for Economic and Strategic Research; 7, Akad. Nikola Obreshkov str., vh. B, ap. 5 Sofia 1113, Bulgaria; tel. (+359 2) 971 2905, 973 3267; fax: (+359 2) 9712871 e-mail:nmarkov@mail.ibn.bg;ndochev@mail.ibn.bg

This research was undertaken with support from the European Community's Phare ACE Programme (ACE Project P97-8131-R "Competitive Pressure and enterprise Adjustment on the Way to EU Accession"). The views expressed in the paper are those of the authors and not of the organizations they are affiliated with. 


\section{NON-TECHNICAL SUMMARY}

The pricing behaviour of Bulgarian manufacturing firms is analyzed in the paper in the context of the theory of the price-setting behaviour of firms endowed with market power, more specifically, using the notion of mark-up pricing. Under perfect competition and assuming perfect markets, producers will sell their products in accordance with their marginal costs. Conversely, deviation from perfect competition and/or perfect markets can be identified by the discrepancy between prices and marginal costs. In the case when the demand curve is downward sloping, this shift results in the formation of a price mark-up, i.e., a situation when the equilibrium price exceeds marginal cost.

Using some recent derivations in the literature (in particular, Roeger's (1995) extension of Hall's (1988) original approach), we estimate mark-up ratios for Bulgarian manufacturing sectors at the NACE 2-digit and NACE 3-digit levels. We use for this purpose balance sheet data for Bulgarian manufacturing enterprises for the period 1995-1997. The estimated numerical values of the mark-up ratios compare favourably with similar results for other countries.

The mark-up ratio reflects the pricing policy of firms endowed with market power who use that power to set prices higher than their marginal costs. Looked from the opposite angle, if the mark-up ratios are measurable, then they themselves can be regarded as reflecting the degree of competition that firms are facing on the market. To test this conjecture, we formulate and estimate a "mark-up price equation" which seeks to explain the cross-sector variation in mark-up ratios through variables measuring competitive pressure within manufacturing sectors. The estimated mark-up equations in the main provide evidence supporting the conjecture that the stronger market competition is a conducive environment for efficient price setting. At the same time, some ambiguity remains as regards the impact of some competition-related variables (such as ownership and exposure to external markets) on the pricing policies of Bulgarian manufacturing firms. 


\section{Introduction}

The existence of competitive markets is an essential prerequisite for productive efficiency and a fundamental requirement for the efficient allocation of resources in the economy; competitive pressure is also a major driving force for innovation at the firm level. The fact that firms in the centrally planned economy operated in the absence of competitive pressure was one of the main factors that contributed for the emergence of built-in allocative and productive inefficiencies (x-inefficiency) and for the generally inefficient resource allocation in these economies. Thus a large part of the legislative, regulatory and institutional reforms initiated and implemented in the CEECs during the past decade were aimed at the creation of a competitive market environment. This was an essential component of the policy effort seeking to enhance the restructuring of enterprise and improve their productive efficiency.

The start of the transition from plan to market in the CEECs in general was featured (although to a varying degree in the different countries) by non-competitive markets, in virtually all aspects outlined above. Market structures were dominated by large, state-owned firms that used to enjoy monopolistic or close to a monopolistic position on the local markets. The degree of openness of the economies was limited, creating a cushion that shielded local firms from competition from abroad. Local product and factor markets were in a rudimentary state, with prevailing state control over domestic prices. Both entry and exit barriers were overwhelming with very little, if any, room left for entrepreneurial activity. All these, in turn, cemented the market power of the large local firms. The prevailing governance structure was that of linear subordination to the central authorities while managerial incentives in the main were dominated by the principles of the command economy.

Although enterprise restructuring was one of the areas of intense research, Relatively few studies have analyzed the firms' pricing behaviour during the transition. Under perfect competition, the equilibrium on the goods market is established when the trading prices equal the firms' marginal costs (put differently, this implies that firms adjust their cost structure so that to set their marginal costs equal to the exogenous price level). However, in the absence of perfect competition, there may be deviations from this model of cost and price formation. Carlin et al. (1999), on the basis of enterprise surveys, find some evidence of a positive correlation between innovation and price mark-up but only in the case of new entrants to the market. 


\section{Pricing behaviour under imperfect competition: Hall's approach and Roeger's transformation}

Under perfect competition and assuming perfect markets, producers will sell their products in accordance with their marginal costs. Conversely, deviation from perfect competition and/or perfect markets can be identified by the discrepancy between prices and marginal costs. Hence, relaxing the assumption of perfect market competition allows to analyze different pricing behaviour and policies of the firms. One of the theoretical models of price formation under the assumption of the existence of monopolistic or oligopolistic market structure is that of "mark-up" pricing (Eichner, 1973; Lavoie, 1996). As known from theory, the presence of a monopolist endowed with market power may result in the shifting of the equilibrium point from the position of perfect competition. In the case when the demand curve is downward sloping, this shift results in the formation of a price mark-up, i.e., a situation when the equilibrium price exceeds marginal cost. In other words, if the market structure is characterized by the incidence of monopolistic/oligopolistic firms, the latter may use their market power to set prices higher than their marginal costs, that is to establish a "mark-up" over the marginal costs:

$$
\mathrm{p}=\theta \mu
$$

where $\mathrm{p}$ is product price, $\mu$ is marginal cost and $\theta$ is the mark-up ratio $(\theta>1)$.

As well known from theory, the mark-up ratio of a profit-maximizing monopolistic firm facing a downward sloping demand curve, is derived in the following form:

$$
\theta=\mathrm{p} / \mu=1 /(1+1 / \eta)
$$

where $\eta$ is the price elasticity of demand.

Mark-up pricing can also be described by the so-called Lerner index:

$$
\mathrm{B}=(\mathrm{p}-\mu) / \mathrm{p}
$$

By virtue of the above definitions: 


$$
\mathrm{B}=1-1 / \theta ; \quad \theta=1 /(1-\mathrm{B})
$$

Looked from a different perspective, the mark-up ratio can be regarded as a forwardlooking measure of the degree of competition that firms are facing on the market. Thus Hall (1988), starting from the assumption that price mark-ups emerge as a result of market power, analyzes the implications of market power on productive efficiency, factor demand and pricing behaviour. For this purpose he derives the Solow residual in the case of imperfect competition and/or markets, when product price does not necessarily equal marginal cost. Hall shows that in this case the difference between the rate of growth of nominal output and the weighted average of factor inputs is not solely attributed to autonomous technical change but may partly reflect monopolistic pricing policy.

This approach is illustrated in the following framework. Assume that output is defined by a standard neo-classical Cobb-Douglas production function with constant returns to scale:

$$
Y_{j}=T_{j} L_{j}^{\alpha} K_{j}^{1-\alpha}
$$

where $K_{j}$ and $L_{j}$ stand for capital and labour inputs, accordingly and $T_{j}$ is a measure of productive efficiency.

As known, profit maximization yields:

$$
\alpha=\mathrm{s}_{\mathrm{wj}}
$$

where $s_{\mathrm{wj}}$ is the share of labour costs in the total firm's costs.

From (5) and (6), the Solow residual which reflects the rate of change of total factor productivity (denoted below as $s_{j}$ ) in the case of perfect competition takes the well known form of:

$$
\mathrm{s}_{\mathrm{j}}=\mathrm{d} \mathrm{y}_{\mathrm{j}}-\alpha\left(\mathrm{d} \mathrm{l}_{\mathrm{j}}\right)-(1-\alpha)\left(\mathrm{d} \mathrm{k}_{\mathrm{j}}\right)
$$

\footnotetext{
${ }^{1}$ As noted by Hall (1988), the equality between price and marginal cost is also a condition for the efficient allocation of resources; conversely, a deviation from this condition implies allocative inefficiency.
} 
where small letters stand for logarithms and "d" denotes the (logarithmic) differences approximating growth rates.

In Hall's (1988) approach, the firm operates under imperfect competition and prices deviate from marginal costs; he shows that in this case the Solow residual computed as (7) can also be decomposed into:

$$
s_{j}=B\left(d y_{j}-d k_{j}\right)+(1-B) d t_{j}
$$

where $\mathrm{B}$ is the above mentioned Lerner index.

In turn, Roeger (1995), using the dual cost function, has derived a similar expression for the dual, or price based Solow residual $\mathrm{s}_{\mathrm{j}}$ :

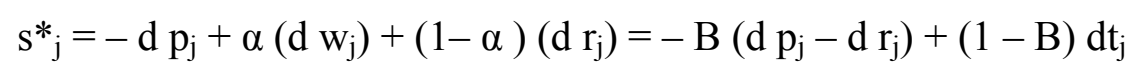

where $P_{j}, W_{j}$ and $R_{j}$ denote firm's price, labour and capital costs, small letters stand for logarithms and "d" for the logarithmic differences

He then subtracts (9) from (8) in which operation the last terms of the two right hand expressions containing the efficiency term cancel out, and after some manipulation and adding an error term, a simple expression is obtained which is at the same time very convenient for estimation:

$$
\begin{aligned}
& \mathrm{s}_{\mathrm{j}}-\mathrm{s}_{\mathrm{j}}=\left(\mathrm{d} \mathrm{y}_{\mathrm{j}}+\mathrm{d} \mathrm{p_{j }}\right)-\alpha\left(\mathrm{d}_{\mathrm{j}}+\mathrm{dw}_{\mathrm{j}}\right)-(1-\alpha)\left(\mathrm{d} \mathrm{k} \mathrm{k}_{\mathrm{j}}+\mathrm{d} \mathrm{r}_{\mathrm{j}}\right)= \\
& =B\left[\left(d y_{j}+d p_{j}\right)-\left(d k_{j}+d r_{j}\right)\right]+\varepsilon_{j}
\end{aligned}
$$

The sums in each of the small brackets are nothing else than the logarithmic differences of the corresponding nominal values: $\mathrm{d} \mathrm{y}^{*_{j}}=\mathrm{d}_{\mathrm{j}}+\mathrm{d} \mathrm{p}_{\mathrm{j}} ; \mathrm{d} \mathrm{l}_{\mathrm{j}}=\mathrm{d} \mathrm{l}_{\mathrm{j}}+\mathrm{d} \mathrm{w}_{\mathrm{j}} ; \mathrm{d} \mathrm{k}{ }_{\mathrm{j}}=$ $d k_{j}+d r_{j}$, where $Y^{*}, L^{*}{ }_{j}$ and $K^{*}{ }_{j}$ denote the nominal values of value added, labour and capital costs, accordingly and the small letters - their logarithms.

Denoting:

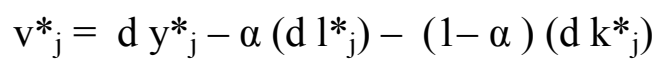

(12) $q^{*}{ }_{j}=d y_{j}-d k^{*}$

the final expression for the estimable equation becomes: 


$$
\mathrm{v}^{*}{ }_{\mathrm{j}}=\mathrm{B} \mathrm{q}{ }^{*}{ }_{\mathrm{j}}+\varepsilon_{\mathrm{j}}
$$

Another appealing feature in Roeger's transformation is that both prices and real variables disappear in the final expressions and so this approach allows to estimate the markup ratios directly from the nominal enterprise data without requiring the knowledge of enterprise or sectoral prices. Also it overcomes the identification problems mentioned by Hall (1988) which arise from the correlation between the explanatory variable and the error term.

Oliveira Martins, Scarpetta and Pilat (1996) have developed further Roeger's transformation to apply for a production function defined over sales and incorporating material inputs as well. ${ }^{\text {E }}$ For example, assume a Cobb-Douglas production function of the type:

$$
Z_{j}=T_{j} L_{j}^{\alpha} M C_{j}^{\beta} K_{j}^{1-\alpha-\beta}
$$

where $Z_{j}, K_{j} M C_{j}$ and $L_{j}$ stand for real sales, capital, material inputs and labour inputs, accordingly and $\mathrm{T}_{\mathrm{j}}$ is the measure of productive efficiency.

Oliveira Martins, Scarpetta and Pilat (1996) show that in this case the corresponding expressions for $\mathrm{v}_{\mathrm{j}}$ and $\mathrm{q}_{\mathrm{j}}$ will take the form:

$$
\mathrm{v}^{*}{ }_{\mathrm{j}}=\mathrm{d} \mathrm{z}_{\mathrm{j}}-\alpha\left(\mathrm{d} \mathrm{H}_{\mathrm{j}}\right)-\beta\left(\mathrm{dmc^{* }}\right)-(1-\alpha-\beta)\left(\mathrm{d} \mathrm{k}_{\mathrm{j}}^{*}\right)
$$

$$
\mathrm{q}^{*} \mathrm{j}_{\mathrm{j}}=\mathrm{d} \mathrm{z}_{\mathrm{j}}-\mathrm{d} \mathrm{k}{ }_{\mathrm{j}}
$$

where $\mathrm{Z}^{*}{ }_{\mathrm{j}}, \mathrm{K}^{*}{ }_{\mathrm{j}} \mathrm{MC}^{*}{ }_{\mathrm{j}}$ and $\mathrm{L}^{*}{ }_{\mathrm{j}}$ stand for nominal sales, capital, material and labour costs, accordingly, while the small letters stand for their logarithms and " $\mathrm{d}$ " for the logarithmic difference; $\alpha=s_{\mathrm{wj}} ; \beta=\mathrm{s}_{\mathrm{mj}}$ are the shares of labour costs and of material costs in total costs,

In this case the derived estimable equation retains its form.

Roeger (1995) and further studies by Oliveira Martins, Scarpetta and Pilat (1996) and Oliveira Martins and Scarpetta (1999) have used the above transformation to estimate sectoral mark-up ratios on the basis of longitudal sectoral data (time series of aggregated

\footnotetext{
${ }^{2}$ The literature is not unanimous on the issue which of the two specifications is more suitable for empirical work. However, as pointed out by Oliveira Martins, Scarpetta and Pilat (1996), some studies have shown that defining the mark-up over value added may induce an upward bias in estimations.
} 
sectoral data). In principle, data allowing (at least two subsequent observations are needed in order to compute the log-differences), there are no theoretical constraints on the application of the above approach to pooled latitudal enterprise data (cross-section), or to mixed enterprise data (panel data). Moreover, this allows in addition to ease one of the possibly rigid assumptions of Hall (1988) and Roeger (1995), incorporated also in all further empirical studies, namely that the mark-ups are time-invariable. In principle, by using cross-sectional data, it is possible to compute mark-up ratios for each available data point.

\section{Estimation of the mark-up ratios for Bulgarian manufacturing firms}

We applied Roeger's transformation to estimate the mark-up ratios in Bulgarian manufacturing by NACE 3-digit and NACE 2-digit sectors, on the basis of the available enterprise data set. We used the extension suggested by Oliveira Martins, Scarpetta and Pilat (1996) corresponding to the mark-up ratios pertaining to sales (implying a production function which is defined over gross output and incorporating material inputs), which seems to be less prone to estimation bias.

We use for this purpose balance sheet data for Bulgarian manufacturing enterprises for the period 1995-1997, as reported to the National Statistical Institute (NSI). An overview of the full sample of Bulgarian manufacturing firms reported by the NSI, broken down by NACE 2-digit sectors, is shown in table 1. This sample is only restricted to firms that apply the "double entry" book accounting standard as only this provides sufficiently detailed breakdown of performance indicators (as needed for our analysis) ${ }^{3}$ Firms in table 1 are defined as private if a majority stake was in private ownership as of the end of the corresponding year (these include both privatized and newly formed private firms); the rest are defined as SOEs.

The estimation procedure is pretty straightforward. First $\mathrm{v}_{\mathrm{j}}$ and $\mathrm{q}{ }_{\mathrm{j}}$ are calculated for each enterprise as shown in (15) and (16) from the individual enterprise data for two adjacent periods. As noted above, only nominal (current price) data are needed for this operation. Then equation (13) is estimated, by selected categories of firms such as manufacturing sectors or another pre-selected sub-set of enterprises. The estimated coefficient of the $\mathrm{q}^{*}$

\footnotetext{
${ }^{3}$ Consequently some private firms (notably individual entrepreneurs) are excluded in our data set altogether.
} 
variable is nothing else than the implied Lerner index. Afterwards, we can calculate backwards the sectoral mark-up ratios $\theta_{\mathrm{i}}$ as shown in (4).

This procedure implies homogeneity of the production technology across the sub-sets of firms for which equation (13) is estimated, and the final result is the average mark-up over marginal cost defined for this pre-specified category of firms. Due to the implications of eventual non-homogeneity of the implied production technology across firms, it is preferable to perform sectoral estimations at a lower level of sectoral disaggregation where it is more likely that this condition would be observed. On the other hand, the sheer number of firms for which data are available becomes a binding lower constraint because already at the NACE 3-digit level there are sectors which are rather under-represented in terms of the number of firms.

Taking into account these conflicting considerations, the above procedure has been applied in two sets of estimations:

1. To estimate the mark-up ratios by NACE 3-digit manufacturing sectors, on the basis of the data for all firms (without discriminating between different categories of firms within the manufacturing sectors). This set of estimations aims at evaluating the average mark-up ratios at the possibly lowest level of disaggregation and the results are given in table 2.

2. To estimate the mark-up ratios by NACE 2-digit sectors, in three versions: a) on the basis of the data for all firms (without discriminating between different categories within manufacturing sectors); b) for the subset of SOEs within each NACE 2-digit sector; c) for the subset of private firms within each NACE 2-digit sector. This set of estimations seeks to distinguish between the pricing patterns of the two main categories of firms (SOEs and private). The results are shown in table 3.

The available data only allow to perform these estimations from 1995 onwards and due to the fact that two adjacent years are needed to estimate the mark-ups in one year, this has reduced the time period to two years: 1996 and 1997. Accordingly, the estimations of equation (15) have been performed separately for each of these years and for a two-year panel.

Due to the implied relationship with the elasticity of demand (2), the mark-up ratio only has a meaningful and straightforward economic interpretation in the case when it is $>1$. As can be seen in the results shown in tables 2 and 3, this has not always been the case in the ratios estimated for the sectoral ratios. Nevertheless, such results are shown in the tables as, because of the rough character of the data and the small number of observations in some 
cases, a possible downward estimation bias may well be within the margin of error. The blanks in the tables are for sectors with no observations (firms) or where a very small number of observations has resulted in implausible degrees of freedom, making the estimation impossible. In a very few number of cases the results were discarded due to very low statistical significance; such sectoral results are not shown in table 7 either.

As to the possibility of an estimation bias, Oliveira Martins, Scarpetta and Pilat (1996) have shown that under the assumption of constant returns to scale, Roeger's approach provides for an unbiased estimate of the Lerner index. However they, as well as Hylleberg and Jørgensen (1998), point out that the presence of increasing returns of scale may result in an downward bias in the estimation of the mark-up and vice versa, decreasing returns to scale may cause an upward bias in the estimation.

Previous studies of Bulgarian enterprise performance (Dobrinsky, Dochev and Markov, 2001) have come up with estimates of returns to scale slightly higher than 1 suggesting that Bulgarian firms in this period operated under increasing returns to scale but this factor was not significantly larger than 1. Such an assumption would lead us to suspect a possible downward bias in the estimated mark-ups. On the other hand, if the measured increasing returns to scale are themselves the result of an estimation bias, and the true returns are assumed as constant, then the estimation risks regarding the mark-ups will be reduced.

Regarding the actual level of the computed mark-ups, to the best of the authors' knowledge, so far similar estimates for Bulgaria have not been documented in the literature, so there is no basis for a critical comparison. On the other hand, the estimated numerical values of the mark-up ratios for Bulgarian manufacturing firms compare favourably with similar results for other transition economies like Hungary (Halpern and Körösi, 2001). Our results are also comparable in level with the sectoral mark-up ratios for the OECD countries computed by Oliveira Martins, Scarpetta and Pilat (1996).

The results presented in table 3 allow a comparison of the pricing policy of SOEs and private firms (as noted, due to the limited number of firms, such a breakdown could only be made at the NACE 2-digit level). Notably, these results do not indicate any systematic deviations in the pricing patterns of these two categories of firms. This is a somewhat counterintuitive finding, as in the transition literature it has usually been taken for granted that SOEs (especially large enterprises) are more likely to enjoy a monopolistic position on the domestic market. Consequently, assuming that SOEs tend to engage more often in monopolistic mark-up pricing practices one would expect to find higher mark-up ratios for the sub-set of SOE than for the sub-set of private firms. In contrast, our results do not 
provide any systematic evidence of this happening. There are indeed cases when the computed sectoral mark-ups are higher than those of the private firms but there are also the examples of the opposite happening.

\section{Competitive pressure and mark-up pricing}

As noted above, by its theoretical definition, the mark-up ratio reflects the pricing policy of firms endowed with market power who use that power to set prices higher than their marginal costs. Hence, looked from the opposite angle, if the mark-up ratios are measurable, then they themselves can be regarded as reflecting the degree of competition that firms are facing on the market. In terms of the empirical statistics used in the framework of our study, such a conjecture would at least imply a positive statistical association between the measured sectoral marukps and the measures of sectoral competitive pressure.

To test this conjecture, we formulate and estimate a "mark-up price equation" which seeks to explain the cross-sector variation in mark-up ratios through variables measuring competitive pressure within manufacturing sectors. Admittedly, in the absence of a proper structural model such an approach has limited analytical power as it is not backed by underlying structural relationships and hence the estimated relationships can only be interpreted in their statistical sense. At the same time such an approach may provide some further clues both as to the overall consistency of the approach and to the adequacy and proper measurement of the mark-ups.

The idea is then to specify the "mark-up price equation" in a form that would allow to analyze (and judge) whether competitive pressure/market power within sectors has a statistically meaningful effect on the price formation in the sectors (as reflected by the computed mark-ups) and if yes, which are the main factors that affect the level of the markups. For this purpose we use as dependent variable the estimated in the previous step markup ratios which should in principle reflect the average addition to marginal costs charged by the firms within individual sectors. As to the independent variables, we use a set of competition variables described below.

We therefore specify a sectoral mark-up price equation for sector i as follows:

$$
\theta_{\mathrm{i}}=b_{\mathrm{i} 0}+\mathrm{b}_{\mathrm{i} 1} \mathrm{C}_{\mathrm{i}}+\mathrm{b}_{\mathrm{i} 2} \mathrm{M}_{\mathrm{i}}+\mathrm{b}_{\mathrm{i} 3} \mathrm{D}_{\mathrm{i}}+\mathrm{b}_{\mathrm{i} 4} \mathrm{E}_{\mathrm{i}}+\mathrm{b}_{\mathrm{i} 5} \mathrm{O}_{\mathrm{i}}+\varepsilon_{\mathrm{i}}
$$


where the following competition variables are used:

$\mathrm{C}_{\mathrm{i}}$ is a measure of the concentration of firms in sector $\mathrm{i}$ (variable $\mathrm{c}_{\mathrm{i} 3}$, the share of the three largest firms in total sectoral sales, was used in the actual estimations). The expected sign of the coefficient is positive.

$\mathrm{M}_{\mathrm{i}}$ is the import penetration ratio in sector i. The sign of the coefficient of this variable is undefined. If the degree of import penetration is assumed to indicate higher competition, then the coefficient should have a negative sign. However, if importers themselves are endowed with market power, the sign may be positive.

$D_{i}$ is the average long-term debt ratio in sector $i$. We assume as above that this indicator mirrors financial pressure on heavily indebted firms and, possibly, the incidence of soft budget constraints reducing competitive pressure. In this interpretation, the expected sign is positive.

$\mathrm{O}_{\mathrm{i}}$ is the share of the sales by state-owned firms in the total sales in sector i. If private ownership is assumed to be associated with better governance and proper incentive structures (and hence higher competitive pressure), then the expected sign of the coefficient of this variable is positive.

$E_{i}$ is the average ratio of exports to sales in sector i. Assuming as above that larger exposure to the international markets is indicative of higher competitive pressure, the coefficient of this variable can be expected to be positive. However, what we observe in our data is the aggregate pricing policy of these firms (covering exports as well as domestic sales) and since exporting firms may have discriminating pricing policies on these two segments of their market, there may be more ambiguity as to this aggregate outcome.

The estimation results for the mark-up price equation specified as above for NACE 3digit manufacturing sectors are shown in table 4. Given the data limitations, the equation was estimated for 1996 and 1997 (single years) and for a 1996-1997 panel, using OLS. Besides, two versions of these estimations are reported in table 4: a) using all computed mark-ups reported in table 2 (including those $<1$ ); b) using only mark-ups $>1$. As noted, in principle only the latter have a meaningful economic interpretation (version b)). In view of the argument in the previous section, version a) assumes that the ratios estimated as $<1$ contain a large margin of error but have captured correctly the relative positioning of the value of the actual mark-up.

In general, the estimation results for the mark-up price equation presented in table 4 can be regarded as satisfactory in terms of the measured direction of impact. The 
concentration variable was estimated with a negative sign (again counter to the expected) but the statistical significance of the estimated coefficient is low (only for the full sample panel it is significant at the $10 \%$ level). The coefficient of the import penetration variable is always positive and statistically significant (at the 5\% level). In terms of the argument above, this would suggest that foreign firms operating on the domestic market tend to enjoy substantial market power which allows them to set monopolistic prices while local firms follow suit. The coefficient of the debt variable is always estimated with a positive sign (in conformity with expectations) and is also statistically significant. This could be interpreted as evidence that financial pressure (and the implied soft budget constraints) is associated with pricesetting practices similar to the monopolistic ones.

As to the variables reflecting export activity and the ownership effect, in most cases the estimated coefficients are not statistically significant while the signs vary in the different versions. In line with expectation, in most cases the estimated coefficients of the ownership variable are positive and for 1997 they are also statistically significant, implying that SOEs firms in that year were more likely to engage in monopolistic price-setting practices. However, most of the coefficients of the ownership variable are not statistically significant, so the estimation results do not provide strong empirical support for this type of argument. As regards the export variable, in more cases this coefficient is negative, but its statistical significance is very low.

\section{Conclusions}

The competition literature argues strongly that when firms are subject to growing competitive pressure, they are motivated to seek ways to enhance their allocative and productive efficiency. Theory also suggests that a competitive environment in well functioning markets is not only propitious for the firms' productive and allocative efficiency but also contributes to the establishment of efficient price-setting mechanisms which are beneficial for consumers as well. Competitive pricing and efficiency are in fact the two sides of one and the same coin.

The transition from plan to market provides an excellent testing ground to test the validity of some of these assumptions and theoretical derivations as the local firms have been facing growing competitive pressures due to the liberalization and opening up of these 
economies. In this paper we attempted to address empirically some aspects of the ongoing process of enterprise restructuring and adjustment in Bulgaria focusing on the impact of competitive pressure on the pricing policies of Bulgarian manufacturing firms.

The pricing policy of Bulgarian manufacturing firms was analyzed in the paper in the context of the theory of the price-setting behaviour of firms endowed with market power, and more specifically, using the notion of mark-up pricing. Using some recent derivations in the literature, we estimate mark-up ratios for Bulgarian manufacturing sectors at the NACE 2digit and NACE 3-digit levels. These estimates have empirical value in themselves, as this aspect of the pricing policy of firms in the transition economies has not been elaborated sufficiently in the literature.

As the sectoral mark-up ratios should reflect the degree of competition that firms are facing within each sector, the paper then goes to test the estimated mark-ups against a set of variables measuring the degree of competitive pressure on a sectoral level. Again, the estimated mark-up equations in the main provide evidence supporting the conjecture that the stronger market competition is a conducive environment for efficient price setting. At the same time, some ambiguity remains as regards the impact of some competition-related variables (such as ownership and exposure to external markets) on the pricing policies of Bulgarian manufacturing firms. 


\section{References}

Carlin, W., Fries, S., Schaffer, M. and Seabright, P. (1999), "Competition, Soft Bidget Constraints and Enterprise Performance in Transition economies", Paper presented at the conference "Ten Years After: Transition and Growth in Post Communist Economies", Warsaw, 15-16 October 1999.

Dobrinsky, R, Dochev, N. and Markov, N. (2001), "Productivity and the Sources of Firm Level Efficiency in Bulgarian Manufacturing", Paper presented at the Workshop on "The determinants of firm level production efficiency in Poland, Romania and Bulgaria: ownership effects, competition effects and implications for EU enlargement", Poiana Brasov, 19-20 January 2001 (co-authors N. Dochev and N. Markov).

Eichner, A. S. (1973), "A Theory of the Determination of the Mark-up Under Oligopoly", Economic Journal, 83(332), pp. 1184-1200.

Hall, R. (1988), “The Relation between Price and Marginal Cost in U.S. Industry", Journal of Political Economy, 96(51), pp. 921-947.

Halpern, L and Körösi, G. (2001), "Mark-ups in Hungarian Corporate Sector”, Paper Presented at the 6th Annual International Conference on Transition Economics, organized by WDI and CEPR, Portoroz, 23 - 26 June 2001.

Hylleberg S. and Jørgensen, R. (1998), "A Note on the Estimation of Markup Pricing in Manufacturing”, University of Aarus Working Paper No. 1998-6.

Lavoie, M. (1996), "Mark-Up Pricing versus Normal Cost Pricing in Post-Keynesian Models", Review of Political Economy, 8(1), pp. 57-66.

Oliveira Martins, J. and Scarpetta, S. (1999), "The Levels and Cyclical Behaviour of Markups across Countries and Market Structures", OECD Economics Department Working Papers No. 213.

Oliveira Martins, J., Scarpetta, S. and Pilat, D. (1996), "Mark-up Ratios in Manufacturing Industries. Estimations for 14 OECD Countries", OECD Economics Department Working Papers No. 162.

Roeger, W. (1995), "Can Imperfect Competition Explain Differences between Primal and Dual Productivity Measures? Estimates for US Manufacturing”, Journal of Political Economy, 103(2), pp. 316-330.

Schaffer, M.E., (1998), "Do Firms in Transition Economies Have Soft Budget Constraints? A Reconsideration of Concepts and Evidence", Journal of Comparative Economics, 26(1), pp. 80-103. 
Table 1. The sample of Bulgarian manufacturing enterprises: number of firms by NACE 2-digit sectors and ownership categories

\begin{tabular}{|c|c|c|c|c|c|c|c|c|c|c|c|c|c|c|c|}
\hline \multirow[b]{2}{*}{ NACE 2-digit sectors } & \multicolumn{3}{|c|}{1994} & \multicolumn{3}{|c|}{1995} & \multicolumn{3}{|c|}{1996} & \multicolumn{3}{|c|}{1997} & \multicolumn{3}{|c|}{1998} \\
\hline & SOEs & Private & Total & SOEs & Private & Total & SOES & Private & Total & SOES & Private & Total & SOES & Private & Total \\
\hline 15 Manufacture of food products and beverages & 372 & 93 & 465 & 380 & 562 & 942 & 380 & 1150 & 1530 & 221 & 1555 & 1776 & 149 & 1858 & 2007 \\
\hline 16 Manufacture of tobacco products & 21 & 1 & 22 & 22 & 3 & 25 & 22 & 9 & 31 & 20 & 7 & 27 & 21 & 9 & 30 \\
\hline 17 Manufacture of textiles and textile products & 126 & 22 & 148 & 127 & 60 & 187 & 125 & 121 & 246 & 51 & 200 & 251 & 40 & 226 & 266 \\
\hline 18 Manufacture of wearing apparel and fur products & 142 & 110 & 252 & 144 & 279 & 423 & 144 & 582 & 726 & 63 & 790 & 853 & 49 & 946 & 995 \\
\hline 19 Manufacture of leather products, luggage and footwear & 43 & 22 & 65 & 43 & 55 & 98 & 42 & 102 & 144 & 13 & 154 & 167 & 10 & 186 & 196 \\
\hline 20 Manufacture of wood products (except furniture) & 75 & 35 & 110 & 76 & 111 & 187 & 82 & 361 & 443 & 40 & 487 & 527 & 27 & 493 & 520 \\
\hline 21 Manufacture of pulp, paper and paper products & 28 & 19 & 47 & 29 & 49 & 78 & 28 & 93 & 121 & 16 & 113 & 129 & 14 & 151 & 165 \\
\hline 22 Publishing, printing and recorded media & 89 & 21 & 110 & 91 & 288 & 379 & 85 & 495 & 580 & 75 & 566 & 641 & 60 & 618 & 678 \\
\hline 23 Manufacture of coke and petroleum products & 5 & 0 & 5 & 4 & 4 & 8 & 4 & 4 & 8 & 1 & 8 & 9 & & 9 & 9 \\
\hline 24 Manufacture of chemicals and chemical products & 72 & 14 & 86 & 74 & 74 & 148 & 71 & 207 & 278 & 42 & 275 & 317 & 33 & 317 & 350 \\
\hline 25 Manufacture of rubber and plastic products & 50 & 12 & 62 & 52 & 77 & 129 & 49 & 286 & 335 & 25 & 364 & 389 & 18 & 364 & 382 \\
\hline 26 Manufacture of other non-metallic mineral products & 128 & 14 & 142 & 128 & 64 & 192 & 138 & 141 & 279 & 78 & 221 & 299 & 64 & 245 & 309 \\
\hline 27 Manufacture of basic metals & 52 & 9 & 61 & 59 & 26 & 85 & 58 & 56 & 114 & 29 & 82 & 111 & 27 & 91 & 118 \\
\hline 28 Manufacture of fabricated metal products & 166 & 38 & 204 & 174 & 177 & 351 & 175 & 523 & 698 & 98 & 625 & 723 & 79 & 656 & 735 \\
\hline 29 Manufacture of machinery and equipment & 282 & 12 & 294 & 285 & 166 & 451 & 312 & 406 & 718 & 159 & 608 & 767 & 130 & 699 & 829 \\
\hline 30 Manufacture of office machinery and computers & 15 & 0 & 15 & 21 & 32 & 53 & 17 & 61 & 78 & 9 & 89 & 98 & 8 & 80 & 88 \\
\hline 31 Manufacture of electrical machinery and apparatus & 75 & 6 & 81 & 75 & 62 & 137 & 73 & 182 & 255 & 39 & 224 & 263 & 34 & 255 & 289 \\
\hline 32 Manufacture of radio, TV and communication equipment & 38 & 3 & 41 & 40 & 51 & 91 & 47 & 103 & 150 & 32 & 122 & 154 & 26 & 125 & 151 \\
\hline 33 Manufacture of precision and optical instruments & 52 & 1 & 53 & 51 & 56 & 107 & 50 & 112 & 162 & 39 & 136 & 175 & 32 & 168 & 200 \\
\hline 34 Manufacture of motor vehicles and trailers & 26 & 2 & 28 & 27 & 11 & 38 & 23 & 40 & 63 & 12 & 52 & 64 & 11 & 59 & 70 \\
\hline 35 Manufacture of other transport equipment & 15 & 1 & 16 & 17 & 26 & 43 & 28 & 46 & 74 & 17 & 58 & 75 & 8 & 73 & 81 \\
\hline 36 Manufacture of furniture & 112 & 40 & 152 & 115 & 147 & 262 & 108 & 309 & 417 & 48 & 422 & 470 & 37 & 439 & 476 \\
\hline 37 Recycling & 4 & 0 & 4 & 4 & 0 & 4 & 1 & 3 & 4 & 1 & 6 & 7 & 1 & 9 & 10 \\
\hline Total & 1988 & 475 & 2463 & 2038 & 2380 & 4418 & 2062 & 5392 & 7454 & 1128 & 7164 & 8292 & 878 & 8076 & 8954 \\
\hline
\end{tabular}

Source: National Statistical Institute. 
Table 2. Estimated mark-up ratios for Bulgarian manufacturing sectors at NACE3-digit level.

\begin{tabular}{|c|c|c|c|c|c|c|c|}
\hline \multirow[t]{2}{*}{$\begin{array}{l}\text { NACE } \\
\text { sectors }\end{array}$} & 1996 & 1997 & $\begin{array}{c}\text { 1996-97 } \\
\text { panel }\end{array}$ & \multirow[t]{2}{*}{$\begin{array}{l}\text { NACE } \\
\text { sectors }\end{array}$} & \multirow{2}{*}{$\begin{array}{c}1996 \\
\begin{array}{c}\text { Mark-up } \\
\text { ratios }\end{array}\end{array}$} & \multirow{2}{*}{$\begin{array}{c}1997 \\
\begin{array}{c}\text { Mark-up } \\
\text { ratios }\end{array}\end{array}$} & \multirow{2}{*}{$\begin{array}{c}\begin{array}{c}1996-97 \\
\text { panel }\end{array} \\
\begin{array}{c}\text { Mark-up } \\
\text { ratios }\end{array}\end{array}$} \\
\hline & $\begin{array}{c}\text { Mark-up } \\
\text { ratios }\end{array}$ & $\begin{array}{c}\text { Mark-up } \\
\text { ratios }\end{array}$ & $\begin{array}{l}\text { Mark-up } \\
\text { ratios }\end{array}$ & & & & \\
\hline 151 & $1.100^{* *}$ & $1.138^{* \star}$ & $1.135^{* *}$ & 268 & 1.023 & $1.141^{\star *}$ & $1.130^{* *}$ \\
\hline 152 & & 0.981 & 0.971 & 271 & 0.940 & 1.428 * & 1.233 \\
\hline 153 & $1.218^{\star *}$ & $1.237^{\star \star}$ & $1.235^{* *}$ & 272 & 0.966 & 1.062 * & 1.043 \\
\hline 154 & 1.445 ** & $1.346^{\star \star}$ & $1.351^{* *}$ & 273 & 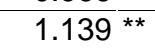 & 1.044 & $1.077^{* *}$ \\
\hline 155 & $1.077^{\star *}$ & $1.047^{\star \star}$ & 1.050 ** & 274 & 0.984 & 1.108 * & $1.102^{* *}$ \\
\hline 156 & 1.248 ** & $1.505^{\star \star}$ & $1.494^{\text {** }}$ & 275 & 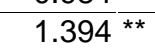 & 1.060 & $1.113^{\text {** }}$ \\
\hline 157 & 1.116 ** & $1.097^{\star *}$ & 1.102 ** & 281 & 1.138 ** & 1.121 ** & 1.121 ** \\
\hline 158 & 1.026 & 1.101 ** & $1.094^{\star \star}$ & 282 & $1.389^{\star \star}$ & $1.190^{\star \star}$ & $1.215^{\star \star}$ \\
\hline 159 & 1.658 ** & 1.082 ** & 1.132 ** & 283 & 0.910 & 1.158 & 1.151 * \\
\hline 160 & 1.284 ** & $1.098^{* *}$ & $1.175^{* *}$ & 284 & 1.370 ** & 1.523 ** & $1.517^{\star *}$ \\
\hline 171 & 1.015 & 1.041 & 1.038 & 285 & $1.146^{\star \star}$ & 1.061 & $1.078^{\star \star}$ \\
\hline 172 & $1.121{ }^{\star \star}$ & 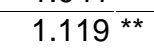 & $1.119^{\star *}$ & 286 & $1.151{ }^{\star \star}$ & $1.197^{\star \star}$ & $1.193^{\star *}$ \\
\hline 174 & 1.029 & 1.396 ** & 1.371 ** & 287 & 1.092 ** & 1.056 ** & 1.060 ** \\
\hline 175 & 1.064 & $1.100^{* \star}$ & $1.092^{* *}$ & 291 & $1.145^{\star \star}$ & $1.114^{\star \star}$ & $1.116^{\text {** }}$ \\
\hline 176 & & 1.372 & 1.372 & 292 & 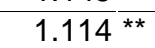 & 1.176 ** & $1.170^{\star *}$ \\
\hline 177 & 1.032 & 1.153 ** & $1.144^{* *}$ & 293 & $1.285^{* *}$ & 1.196 ** & 1.210 ** \\
\hline 181 & 1.287 & 1.137 & 1.160 & 294 & $1.166^{\star \star}$ & 1.210 ** & $1.209^{\text {** }}$ \\
\hline 182 & 1.144 ** & $1.148^{\star \star}$ & $1.148^{* *}$ & 295 & 1.052 ** & $1.167^{\star \star}$ & $1.149^{* *}$ \\
\hline 183 & 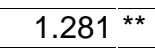 & 1.259 *夫 & 1.261 ** & 296 & 1.412 & 1.248 *夫 & $1.249^{* *}$ \\
\hline 191 & 0.987 & 1.049 & 1.046 & 297 & 1.045 & 1.068 ** & $1.067^{\text {** }}$ \\
\hline 192 & 0.948 & 1.110 ** & $1.105^{\star *}$ & 300 & 1.426 ** & 1.164 ** & $1.173^{\star *}$ \\
\hline 193 & 1.172 *夫 & $1.098^{\star \star}$ & $1.103^{\star *}$ & 311 & 1.018 & $1.127^{\star \star}$ & $1.117^{\text {** }}$ \\
\hline 201 & 1.118 ** & 1.171 ** & $1.167^{* *}$ & 312 & 1.106 ** & 1.122 ** & $1.121^{\text {** }}$ \\
\hline 202 & 1.006 & 1.054 & 1.049 & 313 & 0.976 & 1.190 & 1.181 * \\
\hline 203 & $1.104^{\star \star}$ & $1.067^{\star \star}$ & $1.069^{* *}$ & 314 & 0.977 & 0.973 & 0.973 \\
\hline 204 & 1.072 & 1.055 & 1.056 * & 315 & 0.965 & 1.100 ** & $1.093^{\text {** }}$ \\
\hline 205 & 1.705 * & 1.042 & 1.058 & 316 & 1.031 & $1.167^{\star \star}$ & 1.160 ** \\
\hline 211 & 1.040 & 1.574 ** & $1.556^{\star *}$ & 321 & $1.876^{\star \star}$ & $1.708^{\star \star}$ & $1.718^{\star \star}$ \\
\hline 212 & 1.018 & 1.089 ** & $1.084^{\star *}$ & 322 & $3.447^{\star \star}$ & $1.708^{\star \star}$ & $1.931^{\text {** }}$ \\
\hline 221 & 1.010 & 1.176 ** & 1.172 ** & 323 & 1.094 & 1.312 ** & 1.280 ** \\
\hline 222 & 0.993 & $1.144^{\star \star}$ & $1.137^{\star \star}$ & 331 & 1.066 & $1.141^{\star \star}$ & $1.132^{\star *}$ \\
\hline 223 & & 0.951 & 0.976 & 332 & 1.058 & $1.127^{* \star}$ & 1.120 ** \\
\hline 232 & 0.809 & 1.046 & 1.011 & 333 & 13.782 * & $2.706^{\star \star}$ & $2.773^{\star *}$ \\
\hline 241 & & 1.090 ** & $1.080^{* *}$ & 334 & 1.465 * & $1.368^{* *}$ & $1.370^{* *}$ \\
\hline 242 & 1.002 & 0.990 & 1.008 & 335 & & & 1.139 \\
\hline 243 & 1.141 & $1.180^{\star \star}$ & $1.179^{\star *}$ & 341 & 1.401 & 1.894 ** & $1.888^{* *}$ \\
\hline 244 & 1.087 & $1.188^{\star \star}$ & 1.174 ** & 342 & 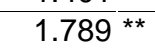 & 1.269 ** & $1.298^{* *}$ \\
\hline 245 & 1.048 & $1.133^{\star *}$ & 1.130 ** & 343 & 1.228 ** & 1.083 * & 1.091 ** \\
\hline 246 & $2.423^{\star \star}$ & $1.606^{\star \star}$ & $1.653^{\star *}$ & 351 & 1.626 ** & 1.172 *夫 & $1.223^{\star *}$ \\
\hline 247 & 0.620 & 0.959 & 0.958 & 352 & & 1.091 * & 1.070 \\
\hline 251 & 1.141 ** & $1.215^{\star \star *}$ & 1.213 ** & 353 & & & 8.241 \\
\hline 252 & $1.087^{\star *}$ & 1.190 ** & $1.185^{* *}$ & 354 & & 1.082 & 1.084 \\
\hline 261 & 0.990 & 1.011 & 1.009 & 355 & & & $0.743^{* *}$ \\
\hline 262 & 1.109 & 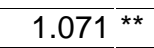 & $1.076^{* *}$ & 361 & $1.088^{* *}$ & 1.081 ** & 1.082 ** \\
\hline 263 & 1.280 ** & 1.109 & 1.199 ** & 362 & 1.029 & 0.982 & 0.984 \\
\hline 264 & 1.104 ** & $1.053^{\star \star}$ & $1.068^{* *}$ & 364 & 0.744 & 1.020 & 0.991 \\
\hline 265 & 0.963 & $1.245^{\star *}$ & $1.191^{\star *}$ & 365 & 1.269 & 1.509 ** & 1.495 \\
\hline 266 & 1.055 & 1.035 ** & $1.038^{* *}$ & 366 & 1.583 ** & 1.091 ** & 1.112 \\
\hline 267 & 1.086 & 1.226 ** & $1.216^{\star *}$ & 372 & & $1.257^{\star}$ & 1.257 \\
\hline
\end{tabular}

** - significant at the $5 \%$ significance level; * - significant at the $10 \%$ significance level

Note: The significance levels refer to the Lerner indices estimated in accordance with equation (15). For details see text.

Source: Authors' calculations 
Table 3. Estimated mark-up ratios for Bulgarian manufacturing sectors at NACE 2-digit level by ownership categories.

\begin{tabular}{|c|c|c|c|c|c|c|c|c|c|}
\hline \multirow{2}{*}{$\begin{array}{l}\text { NACE } \\
\text { sectors }\end{array}$} & \multicolumn{3}{|c|}{ All firms } & \multicolumn{3}{|c|}{ SOES } & \multicolumn{3}{|c|}{ Private firms } \\
\hline & 1996 & 1997 & $\begin{array}{c}1996-1997 \\
\text { panel }\end{array}$ & 1996 & 1997 & $\begin{array}{c}\text { 1996-1997 } \\
\text { panel }\end{array}$ & 1996 & 1997 & $\begin{array}{c}1996-1997 \\
\text { panel }\end{array}$ \\
\hline 15 & $1.168^{* *}$ & $1.057^{\star *}$ & $1.066^{* \star}$ & $1.133^{\star *}$ & $1.042^{* \star}$ & $1.056^{* *}$ & $1.203^{* *}$ & $1.066^{* *}$ & $1.072^{* *}$ \\
\hline 16 & 1.059 & 0.916 & 0.975 & $1.267^{\star *}$ & 1.000 & $1.066^{* *}$ & & 0.888 & 1.077 \\
\hline 17 & $1.066^{\star *}$ & 1.078 ** & $1.077^{\star \star}$ & $1.104^{\star *}$ & 1.018 & $1.029^{\star *}$ & 0.981 & $1.136^{\star *}$ & $1.127^{\star \star}$ \\
\hline 18 & $1.061^{\star \star}$ & $1.053^{* *}$ & $1.054^{\star \star}$ & $1.242^{\star \star}$ & $1.075^{\star \star}$ & $1.102^{\star \star}$ & $1.071^{\star \star}$ & $1.103^{\star *}$ & $1.101^{\star \star}$ \\
\hline 19 & 1.051 & 1.043 * & $1.044^{\star *}$ & $1.169^{* *}$ & 1.025 & $1.043^{* *}$ & 1.069 & $1.088^{* *}$ & $1.088^{\star *}$ \\
\hline 21 & 1.038 & $1.128^{\star *}$ & $1.123^{* *}$ & 1.065 & 1.326 ** & $1.307^{* *}$ & 0.977 & 1.063 * & $1.059^{* *}$ \\
\hline 22 & 1.017 & $1.086^{* *}$ & $1.084^{\star \star}$ & 0.971 & 1.002 & 0.998 & 0.903 & $1.109^{* *}$ & $1.108^{\star \star}$ \\
\hline 23 & 1.362 & 1.031 & 1.102 & 0.881 & 1.026 & 0.983 & & 1.947 & 1.947 \\
\hline 24 & 1.152 ** & 1.027 & 1.035 & $1.233^{\star \star}$ & $1.139^{\star \star}$ & $1.149^{\star *}$ & 0.969 & $1.097^{\star \star}$ & $1.093^{\star *}$ \\
\hline 25 & $1.115^{\star *}$ & $1.173^{* *}$ & 1.171 ** & 1.100 ** & 1.017 & $1.028^{\star *}$ & 1.061 & $1.206^{\star *}$ & $1.204^{\star \star}$ \\
\hline 26 & 0.979 & 1.011 & 1.005 & $1.137^{\star \star}$ & 1.068 ** & $1.080^{* *}$ & 0.992 & $1.045^{\star *}$ & $1.035^{* *}$ \\
\hline 27 & 1.354 ** & $0.915^{* *}$ & 0.975 & $1.334^{\star *}$ & 1.040 & $1.088^{* *}$ & 1.012 & $1.077^{*}$ & 1.065 * \\
\hline 28 & $1.171^{\star \star}$ & $1.123^{* *}$ & $1.127^{\star \star}$ & $1.172^{\star \star}$ & $1.042^{\star \star}$ & $1.065^{\star *}$ & 1.149 ** & $1.067^{\star \star}$ & $1.069^{\star \star}$ \\
\hline 30 & 1.094 & 1.005 & 1.008 & 1.484 ** & 1.070 & $1.119^{*}$ & & 1.000 & 1.000 \\
\hline 31 & 1.010 & $1.116^{* *}$ & $1.108^{* *}$ & 1.027 & 1.044 ** & $1.041^{\star *}$ & 1.436 * & $1.055^{* *}$ & $1.055^{\star *}$ \\
\hline 32 & 1.522 ** & $1.117^{\star *}$ & $1.159^{* *}$ & 2.642 ** & $1.447^{\star *}$ & $1.565^{* *}$ & $1.725 *$ & $1.314^{* *}$ & $1.341^{* *}$ \\
\hline 33 & 1.054 & 1.036 & 1.037 & $1.565^{\star *}$ & 1.067 ** & $1.127^{\star *}$ & & 1.079 ** & $1.079^{\star *}$ \\
\hline 34 & 1.188 ** & 0.988 & 0.999 & $1.429 * *$ & $1.237^{* *}$ & $1.259^{* *}$ & $2.773^{\star *}$ & $1.107^{*}$ & $1.120^{* *}$ \\
\hline 35 & 1.212 * & 1.103 & 1.114 * & $1.346^{\star *}$ & 1.090 ** & $1.124^{\star \star}$ & & 1.069 & 1.069 \\
\hline 36 & $1.073^{\star *}$ & 1.042 * & $1.045^{\star *}$ & $1.106^{\star *}$ & 1.007 & 1.018 & $1.100^{\star \star}$ & 1.101 ** & $1.101^{\star \star}$ \\
\hline
\end{tabular}

** - significant at the 5\% significance level; * - significant at the $10 \%$ significance level

Note: The significance levels refer to the Lerner indices estimated in accordance with equation (15). For details see text.

Source: Authors' calculations 
Table 4. OLS estimations of the mark-up equation

Dependent variable: price mark-up ratios at NACE 3-digit level

(t-statistics in parentheses)

\begin{tabular}{|c|c|c|c|c|c|c|}
\hline \multirow{3}{*}{$\begin{array}{l}\text { Estimated } \\
\text { sample } \\
\text { Year/period } \\
\text { Number of } \\
\text { observations }\end{array}$} & \multicolumn{3}{|c|}{ All sectors } & \multicolumn{3}{|c|}{$\begin{array}{c}\text { Sectors with positive } \\
\text { mark-up ratios }\end{array}$} \\
\hline & 1996 & 1997 & $\begin{array}{l}1996-97 \\
\text { panel }\end{array}$ & 1996 & 1997 & $\begin{array}{l}\text { 1996-97 } \\
\text { panel }\end{array}$ \\
\hline & 81 & 85 & 166 & 66 & 80 & 146 \\
\hline Constant & $\begin{array}{l}1.115 \star \star \\
(6.722)\end{array}$ & $\begin{array}{l}1.066 * \star \\
(20.894)\end{array}$ & $\begin{array}{l}1.094 * \star \\
(16.595)\end{array}$ & $\begin{array}{l}1.094 * \star \\
(5.660)\end{array}$ & $\begin{array}{l}1.049 \star \star \\
(20.953)\end{array}$ & $\begin{array}{l}1.032 \star \star \\
(14.845)\end{array}$ \\
\hline ci3 & $\begin{array}{l}-0.274 \\
(-1.476)\end{array}$ & $\begin{array}{l}-0.091 \\
(-1.230)\end{array}$ & $\begin{array}{l}-0.157 \star \\
(-1.733)\end{array}$ & $\begin{array}{l}-0.023 \\
(-0.095)\end{array}$ & $\begin{array}{l}-0.048 \\
(-0.655)\end{array}$ & $\begin{array}{l}-0.044 \\
(-0.449)\end{array}$ \\
\hline M & $\begin{array}{l}0.389 * \star \\
(2.314)\end{array}$ & $\begin{array}{l}0.219 * * \\
(3.429)\end{array}$ & $\begin{array}{l}0.294 * \star \\
(3.540)\end{array}$ & $\begin{array}{l}0.359 * \star \\
(1.821)\end{array}$ & $\begin{array}{l}0.219 * \star \\
(3.492)\end{array}$ & $\begin{array}{l}0.273 * \star \\
(3.111)\end{array}$ \\
\hline $\mathrm{D}$ & $\begin{array}{l}0.640 * \star \\
(2.477)\end{array}$ & $\begin{array}{l}0.469 * \star \\
(2.759)\end{array}$ & $\begin{array}{l}0.565 \star \star \\
(3.549)\end{array}$ & $\begin{array}{l}0.538 * \\
(1.862)\end{array}$ & $\begin{array}{l}0.448 * \star \\
(2.711)\end{array}$ & $\begin{array}{l}0.518 * \star \\
(3.162)\end{array}$ \\
\hline OD & $\begin{array}{l}0.047 \\
(0.218)\end{array}$ & $\begin{array}{l}0.154 \star \star \\
(2.558)\end{array}$ & $\begin{array}{c}0.067 \\
(0.986)\end{array}$ & $\begin{array}{l}-0.075 \\
(-0.265)\end{array}$ & $\begin{array}{l}0.182 \star \star \\
(3.028)\end{array}$ & $\begin{array}{l}0.113 \\
(1.552)\end{array}$ \\
\hline $\mathrm{ED}$ & $\begin{array}{l}-0.035 \\
(-0.163)\end{array}$ & $\begin{array}{l}-0.018 \\
(-0.192)\end{array}$ & $\begin{array}{l}-0.050 \\
(-0.431)\end{array}$ & $\begin{array}{l}0.108 \\
(0.403)\end{array}$ & $\begin{array}{l}-0.036 \\
(-0.379)\end{array}$ & $\begin{array}{c}0.002 \\
(0.018)\end{array}$ \\
\hline Adjusted R2 & 0.116 & 0.213 & 0.138 & 0.049 & 0.251 & 0.121 \\
\hline
\end{tabular}

** - significant at the 5\% significance level;

* - significant at the $10 \%$ significance level.

Source: Authors' calculations 


\section{DAVIDSON INSTITUTE WORKING PAPER SERIES - Most Recent Papers}

The entire Working Paper Series is available at: www.wdi.bus.umich.edu

CURRENT AS OF 10/2/01

\begin{tabular}{|c|c|c|}
\hline Publication & Authors & Date \\
\hline No. 389: Mark-Up Pricing In Bulgarian Manufacturing & $\begin{array}{l}\text { Rumen Dobrinsky, Boyko } \\
\text { Nikolov, and Nikolay Markov }\end{array}$ & June 2001 \\
\hline $\begin{array}{l}\text { No. } 388 \text { Globalization and Firms' Financing Choices: } \\
\text { Evidence from Emerging Economies }\end{array}$ & $\begin{array}{l}\text { Sergio Schmukler and Esteban } \\
\text { Vesperoni }\end{array}$ & May 2001 \\
\hline $\begin{array}{l}\text { No. } 387 \text { The Distributional Impacts of Indonesia's Financial Crisis on } \\
\text { Household Welfare: A "Rapid Response" Methodology }\end{array}$ & $\begin{array}{l}\text { Jed Friedman and James } \\
\text { Levinsohn }\end{array}$ & Sept. 2001 \\
\hline $\begin{array}{l}\text { No. } 386 \text { Corporate Financial Policies and Performance Prior to Currency } \\
\text { Crises }\end{array}$ & $\begin{array}{l}\text { Arturo Bris, Yrjö Koskinen, and } \\
\text { Vicente Pons }\end{array}$ & June 2001 \\
\hline No. 385 Ownership and Productive Efficiency: Evidence from Estonia & Derek C. Jones and Niels Mygind & Aug. 2001 \\
\hline $\begin{array}{l}\text { No. } 384 \text { Forthcoming in: Journal of Economic Perspectives, } \\
\text { "Institutional Determinants of Labor Reallocation in Transition" Vol. } \\
\text { 16, No. 2, Feb. } 2002 .\end{array}$ & Tito Boeri and Katherine Terrell & June 2001 \\
\hline $\begin{array}{l}\text { No. } 383 \text { Deindustrialisation and Structural Change During the Post- } \\
\text { Communist Transition }\end{array}$ & $\begin{array}{l}\text { Tomasz Mickiewicz and Anna } \\
\text { Zalewska }\end{array}$ & June 2001 \\
\hline No. 382 Markets and Growth & Štěpán Jurajda and Janet Mitchell & July 2001 \\
\hline $\begin{array}{l}\text { No. } 381 \text { Labor Market Discrimination During Post-Communist } \\
\text { Transition: A Monopsony Approach to the Status of Latvia's Russian } \\
\text { Minority }\end{array}$ & Robert S. Chase & Sept. 2000 \\
\hline No. 380 Dollarization of Liabilities in Non-tradable Goods Sector & Frédéric Chabellard & June 2001 \\
\hline $\begin{array}{l}\text { No. } 379 \text { Lessons from the Russian Meltdown: The Economics of Soft } \\
\text { Legal Constraints }\end{array}$ & Enrico Perotti & Mar. 2001 \\
\hline No. 378 Effective Tax Rates in Transition & Vlad Iva & May 2001 \\
\hline $\begin{array}{l}\text { No. } 377 \text { Some Explanations for Changes in the Distribution of } \\
\text { Household Income in Slovakia: } 1988 \text { and } 1996\end{array}$ & $\begin{array}{l}\text { Thesia Garner and Katherine } \\
\text { Terrell }\end{array}$ & May 2001 \\
\hline $\begin{array}{l}\text { No. } 376 \text { Competition and Enterprise Performance in Transition } \\
\text { Economies: Evidence from a Cross-country Survey }\end{array}$ & $\begin{array}{l}\text { Wendy Carlin, Steven Fries, } \\
\text { Mark Schaffer and Paul Seabright }\end{array}$ & May 2001 \\
\hline $\begin{array}{l}\text { No. } 375 \text { Why More is Actually Less: New Interpretations of China's } \\
\text { Labor-Intensive FDI }\end{array}$ & Yasheng Huang & May 2001 \\
\hline No. 374 Economic Fragmentation and FDI in China & Yasheng Huang & May 2001 \\
\hline $\begin{array}{l}\text { No. } 373 \text { Earnings Disparities in the Czech Republic: Evidence of the } \\
\text { Past Decade and Cross-National Comparison }\end{array}$ & Jiri Vecernik & May 2001 \\
\hline $\begin{array}{l}\text { No. } 372 \text { Economic Reform, Democracy and Growth During Post- } \\
\text { Communist Transition }\end{array}$ & Jan Fidrmuc & Mar. 2001 \\
\hline $\begin{array}{l}\text { No. } 371 \text { Do Multinational Enterprises Substitute Parent Jobs for Foreign } \\
\text { Ones? Evidence from Firm Level Panel Data }\end{array}$ & Jozef Konings and Alan Murphye & Apr. 2001 \\
\hline $\begin{array}{l}\text { No. } 370 \text { From Needs to the Market: Changing Inequality of Household } \\
\text { Income in the Czech Transition }\end{array}$ & Jiri Vecernik & Apr. 2001 \\
\hline $\begin{array}{l}\text { No. } 369 \text { Competition and Corporate Governance: Substitutes or } \\
\text { Complements? Evidence from the Warsaw Stock Exchange }\end{array}$ & $\begin{array}{l}\text { Irena Grosfeld and Thierry } \\
\text { Tressel }\end{array}$ & Mar. 2001 \\
\hline $\begin{array}{l}\text { No. } 368 \text { Multinational Corporations as Catalyst for Industrial } \\
\text { Development: The Case of Poland }\end{array}$ & $\begin{array}{l}\text { Carlo Altomonte and Laura } \\
\text { Resmini }\end{array}$ & Feb. 2001 \\
\hline No. 367 A Multi-Task Theory of the State Enterprise Reform & $\begin{array}{l}\text { Chong-En Bai, David D. Li, } \\
\text { Zhigang Tao, and Yijiang Wang }\end{array}$ & Mar. 2001 \\
\hline No. 366a Confidence Building in Emerging Stock Markets & Enrico C. Perotti and Luc Laeven & June 2001 \\
\hline No. 366 Confidence Building in Emerging Stock Markets & $\begin{array}{l}\text { Enrico C. Perotti, Luc Laeven, } \\
\text { and Pieter van Oijen }\end{array}$ & Dec. 2000 \\
\hline $\begin{array}{l}\text { No. } 365 \text { Incentive Contracting versus Ownership Reforms: Evidence } \\
\text { from China's Township and Village Enterprises }\end{array}$ & $\begin{array}{l}\text { Chun Chang, Brian McCall, and } \\
\text { Yijang Wang }\end{array}$ & Nov. 2000 \\
\hline $\begin{array}{l}\text { No. } 364 \text { Individual Pay and Outside Options: Evidence from the Polish } \\
\text { Labour Force Survey }\end{array}$ & $\begin{array}{l}\text { Fiona Duffy and Patrick Paul } \\
\text { Walsh }\end{array}$ & Mar. 2001 \\
\hline
\end{tabular}

